\title{
KONSEP PENDIDIKAN ISLAM DALAM PERSPEKTIF K.H. AHMAD DAHLAN
}

\author{
Dhian Wahana Putra \\ Dosen Program Studi Pendidikan Agama Islam Fakultas Agama Islam \\ Universitas Muhammadiyah Jember \\ Email: dhianwahana@unmuhjember.ac.id
}

\begin{abstract}
Education has become a "trademark" in Muhammadiyah movement, as a concrete form of the role of Muhammadiyah in empowering Muslims and the intellectual minds of the nation. Discussion of Muhammadiyah-based education cannot be separated from the figure of K.H. Ahmad Dahlan, involving the focus of ultimate truth to capture what was implicit in AlManaar's interpretation so that although he did not have a western education, he was able to open the gate of rationality through the teachings of Islam itself, which was called ijtihad. By rejecting taqlid. KH. Ahmad Dahlan can be regarded as a "model" in the generation of revival which is a "central point" of a movement that appears to overcome the challenges facing Islam in the form of backwardness and stagnation in the Islamic educational system. Unlike a number of national figures in his days who were more concerned with political and economic issues, K.H. Ahmad Dahlan devoted himself fully in the field of education. Based on this description, this study aimed to investigate the concept of Islamic education from KH. Ahmad Dahlan's perspectives. In particular, the direction of this study was to understand the goals of Islamic education according to K.H. Ahmad Dahlan, the conceptualisation of Islamic education curriculum according to $K$. Ahmad Dahlan, as well as the methods of Islamic educational practice according to K. AH Ahmad Dahlan. The study was library research with the technique for data collection including documentation conducted through looking for data about things or variables in the form of notebook transcripts, newspapers, magazines, inscriptions, minutes, meetings, agendas, and so on. Data analysis were carried out through descriptive analysis. The findings of this study revealed that the perspectives of KH. Ahmad Dahlan about Islamic education: first, the aim of Islamic education is to maintain the purity of human beings; second, the curriculum is integral; third, and the method of hiwar/repetition, balance and proportionality between theory and practice was used.
\end{abstract}

Kata Kunci: Pendidikan Islam, Perspektif KH Ahmad Dahlan

PENDAHULUAN

K.H. Ahmad Dahlan lahir di Kauman Yogyakarta pada 1 Agustus tahun 1868 dan meninggal pada tanggal

23 Februari 1921. Nama kecilnya adalah

Muhammad Darwis. Ia berasal dari 
keluarga yang didaktis dan terkenal alim dalam ilmu agama. Ayahnya bernama K.H. Abu Bakar, seorang Imam dan khatib Masjid besar KratonYogyakarta. Sementara ibunya bernama Siti Aminah, putri K.H. Ibrahim yang pernah menjabat sebagai penghulu di Kraton Yogyakarta (Ar-Rasyidin, 2005: 100). Menurut Syamsul Nizar (2002: 101) Ahmad Dahlan dididik dalam lingkungan pesantren sejak kecil yang mengajarinya pengetahuan agama dan bahasa Arab. Setelah beberapa waktu belajar dengan sejumlah guru di tanah kelahiranya, pada tahun 1890 Ahmad Dahlan berangkat ke Makkah untuk melanjutkan studinya dan bermukim disana selama setahun. Merasa tidak puas dengan hasil kunjungannya yang pertama, maka pada tahun 1903, ia berangkat lagi ke Mekah dan menetap dua tahun, ketika mukim yang kedua kali ini, ia banyak bertemu dan melakukan muzakkarah dengan sejumlah ulama Indonesia yang bermukim di Mekah.

Diantara ulama tersebut adalah:

Syekh Muhammad Khatib alMinangkabawi, Kiyai Nawawi AlBanteni, Kiyai Mas Abdullah, dan Kiyai Faqih Rembang (Syamsul Nizar, 2002: 101). Menurut Khozin (2005: 10) pada saat itu pula ia juga berinteraksi dengan pemikiran-pemikiran pembaru dalam dunia Islam, seperti Muhammad Abduh, Jamaludin Al-Afghani, Rasyid Ridha, dan Ibn Taimiyah. Buah pemikiran tokohtokoh Islam ini mempunyai pengaruh yang besar pada Ahmad Dahlan. Jiwa dan pemikirannya penuh disemangati oleh aliran pembaharuan ini yang kelak kemudian hari menampilkan corak keagamaan yang sama, yaitu melalui Muhammadiyah, yang bertujuan untuk memperbaharui pemahaman keagamaan (ke Islaman) di sebagian besar Islam Indonesia saat itu yang masih bersifat ortodoks (kolot).

Tanpa mengurangi pemikiran para intelektual muslim lainya, paling tidak pemikiran Ahmad Dahlan tentang pendidikan Islam dapat dikatakan sebagai awal kebangkitan pendidikan Islam di Indonesia. Gagasan pembaruanya sempat mendapat tantangan dari masyarakat waktu itu, terutama dari lingkungan pendidikan tradisional, kendati demikian bagi Ahmad Dahlan tantangan tersebut bukan merupakan hambatan, melainkan tantangan yang perlu dihadapi secara arif dan bijaksana. Arus dinamika pembaruan terus mengalir dan bergerak menuju kepada berbagai pesoalan kehidupan yangn semakin kompleks.

Dengan demikian, peranan pendidikan Islam menjadi semakin penting dan strategis untuk senantiasa mendapat perhatian yang serius. Hal ini disebabkan karena pendidikan merupakan media yang strategis untuk mencerdaskan umat. Melalui media ini umat akan semakin kritis dan memiliki daya analisa yang tajam dalam membaca peta kehidupan masa depannya yang dinamis. Dalam konteks ini, setidaknya pemikiran pendidikan Ahmad Dahlan dapat diletakkan sebagai upaya sekaligus wacana untuk memberikan inspirasi bagi pembentukan dan pembinaan peradaban umat masa depan yang lebih proporsional. Sekarang konteks yang dihadapi tidak lagi sama dengan konteks yang dihadapi Ahmad Dahlan, sekarang sudah dihadapkan ke tuntutan global untuk itu bagaimana pendidikan Muhammadiyah mampu menyesuaikan tuntutan itu namun 
tetap dengan cita-cita awal sesuai yang diharapkan pendirinya yaitu KH. Ahmad Dahlan. Rumusan masalah penelitian yaitu : (1) Bagaimana tujuan pendidikan Islam menurut KH. Ahmad Dahlan?; (2) Bagimana konsep kurikulum pendidikan Islam menurut KH. Ahmad Dahlan?; dan (3) Bagaimana metode pendidikan Islam menurut KH. Ahmad Dahlan? Penelitian ini bertujuan untuk mendeskripikan dan memahami secara kongkrit tujuan, kurikulum dan metode pendidikan Islam dalam perspektif KH. Ahmad Dahlan.

\section{METODE PENELITIAN}

Penelitian ini menggunakan pendekatan kualitatif dimana data-data yang didapatkan tanpa menggunakan angka. Peneliti memilih pendekatan kualitatif karena dirasa lebih jelas dan lebih luas dalam pembahasan. Penggunaan pendekatan kualitatif dimaksudkan untuk memperoleh data asli dan alamiah. Artinya suatu data yang sesuai dengan keadaan sesungguhnya dan memiliki makna mendalam, sehingga melalui pendekatan kualitatif setiap fenomena yang ada dilapangan dan berkaitan dengan tujuan penelitian dapat dipahami secara utuh dan mendalam sesuai dengan kenyataan sebenarnya.

Jenis penelitian ini adalah penelitian pustaka (Libray Research) yaitu menampilkan argumentasi penalaran keilmuan yang memaparkan hasil-hasil kajian pustaka, hasil olah pikir peneliti mengenai satu masalah atau topik kajian.

Kajian ini memuat atau menggali gagasan yang terkait dengan topik kajian dan harus didukung oleh data atau informasi yang diperoleh dari sumber pustaka (Literature), penulis memilih dan mengkaji secara historis dan filosofis bahan-bahan yang berkaitan dengan konsep pendidikan menurut KH. Ahmad Dahlan.

\section{HASIL PENELITIAN DAN PEMBAHASAN}

\section{Tujuan Pendidikan Menurut KH Ahmad Dahlan}

Menurut KH. Ahmad Dahlan, pendidikan islam hendaknya diarahkan pada usaha membentuk manusia muslim yang berbudi pekerti luhur, alim dalam agama, luas pandangan dan paham masalah ilmu keduniaan, serta bersedia berjuang untuk kemajuan masyarakatnya (Hery Sucipto, 2010: 123). Tujuan pendidikan tersebut merupakan pembaharuan dari tujuan pendidikan yang saling bertentangan pada saat itu yaitu pendidikan pesantren dan pendidikan sekolah model Belanda. Di satu sisi pendidikan pesantren hanya bertujuan utnuk menciptakan individu yang shalih dan mendalami ilmu agama. Sebaliknya, pendidikan sekolah model Belanda merupakan pendidikan sekuler yang didalamnya tidak diajarkan agma sama sekali. Akibat dualisme pendidikan tersebut lahirlah dua kutub intelegensia: lulusan pesantren yang menguasai agama tetapi tidak menguasai ilmu umum dan sekolah Belanda yang menguasai ilmu umum tetapi tidak menguasai ilmu agama.

Melihat ketimpangan tersebut $\mathrm{KH}$. Ahmad Dahlan berpendapat bahwa tujuan pendidikan yang sempurna adalah melahirkan individu yang utuh menguasai ilmu agama dan ilmu umum, material dan 
spritual serta dunia dan akhirat. Sebagai usaha untuk mencapai cita-cita tersebut K.H. Ahmad Dahlan menempuh cara dengan mendirikan lembaga-lembaga pendidikan tempat ilmu-ilmu sekuler dan agama akan diberikan (Alwi Shihab, 1998: 205). Bagi K.H. Ahmad Dahlan kedua hal tersebut (agama-umum, material-spritual dan dunia-akhirat) merupakan hal yang tidak bisa dipisahkan satu sama lain. Inilah yang menjadi alasan mengapa KH. Ahmad Dahlan mengajarkan pelajaran agama mencoba menggugat praktik pendidikan islam pada masanya. Pada waktu itu, pelaksanaan pendidikan hanya dipahami sebagai proses pewarisan adat dan sosialisasi perilaku individu maupun sosial yang telah menjadi model baku dalam masyarakat. Pendidikan tidak memberikan kebebasan kepada peserta didik untuk berkreasi dan mengambil prakarsa. Kondisi yang demikian menyebabkan pelaksanaan pendidikan berjalan searah dan tidak bersifat dialogis.

Padahal menurut Dahlan, pengembangan daya kritis, sikap dialogis, menghargai potensi akal dan hati yang suci, merupakan strategi bagi peserta didik mencapai pengetahuan tertinggi dan batasan ini terlihat bahwa dahlan ingin meletakkan visi dasar bagi reformasi pendidikan islam melalui penggabungan sistem pendidikan modern dan tradisional secara harmonis dan integral. hal senada diungkapkan oleh Abdul Mu'ti dalam tulisannya yang berjudul "Kurikulum Qu'ani” (2012: 84), yaitu: “ Muhammadiyah mengembangkan metode pembelajaran dialogis dan pendekatan rasional dalam pembelajaran agama". Hal ini sesuai dengan ciri sebagai gerakan modern, yaitu semangat untuk membangun tatanan sosial masyarakat yang lebih maju dan terdidik (Hery Sucipto, 2010: 172). Upaya untuk mencapai tujuan ini proses pendidikan islam hendaknya mengakomodasi berbagai ilmu pengetahuan, baik umum ataupun agama, untuk mempertajam daya intelektualitas dan memperkokoh spiritualitas peserta didik upaya akan terealisasi manakala proses pendidikan bersifat integral proses pendidikan yang demikian pada gilirannya akan mampu menghasilkan alumni "intelektualisasi ulama" dan ilmu umum sekaligus di Madrasah Muhammadiyah.

Sehingga dalam hasil penelitian ini dapat digaris bawahi tujuan pendidikan islam menurut K.H. Ahmad Dahhlan sebagaimana dipaparkan dalam deskripsi diatas, dapat diambil kesimpulan sebagai berikut:

(1) Pendidikan islam hendaknya diarahkan pada usaha membentuk manusia muslim yang berbudi pekerti luhur, alim dalam agama, luas pandangan dan paham masalah ilmu keduniaan, serta bersedia berjuang untuk kemajuan masyarakatnya,

(2) Tujuan pendidikan yang sempurna adalah melahirkan individu yang utuh menguasai ilmu agama dan ilmu umum, material dan spritual serta dunia dan akhirat,

(3) Mempertajam daya intelektualitas dan memperkokoh spiritualitas.

\section{Konsep Kurikulum Pendidikan Islam menurut KH. Ahmad Dahlan}

Dalam buka yang berjudul K.H. Ahmad Dahlan Sang Pencerah, Pendidik 
dan Pendiri Muhammadiyah (Hery Sucipto, 2010: 119) tertulis sebagai berikut:

"Menurut K.H. Ahmad Dahlan, pelaksanaan pendidikan hendaknya didasarkan pada landasan yang kokoh yaitu Al-Qur'an dan Sunnah. Landasan ini merupakan kerangka filosofis untuk merumuskan konsep dan tujuan ideal pendidikan Islam, baik secara vertikal (khaliq) maupun horizontal (makhluk). Dalam Islam paling tidak ada dua sisi tugas penciptaan manusia, yaitu 'abd Allah (hamba Allah) dan khalifah fi alardh (wakil Allah di bumi)."

Agar konsep tersebut tercapai, maka materi pendidikan menurut Dahlan, adalah pengajaran Al-Qur'an, Hadits, membaca, menulis, berhitung, ilmu bumi dan menggambar. Materi Al-Qur'an dan Hadits meliputi ibadah, persamaan derajat, fungsi perbuatan manusia dalam menentukan nasibnya, musyawarah, pembuktian pembenaran Al-Qur'an dan Hadits menurut akal, kerjasama antara agama-kebudayaan-kemajuan peradaban, hukum kausalitas perubahan, nafsu dan kehendak, domokratisasi dan liberalisasi, kemerdekaan berpikir, dinamika kehidupan dan peranan manusia di dalamnya, dan akhlaq (budi pekerti). Dengan demikian muatan kurikulum dalam sekolah Muhammadiyah terdapat dua aspek, yaitu muatan kurikulum umum dan muatan kurikulum agama. Dalam hal kurikulum K.H. Ahmad Dahlan juga merintis pembelajaran agama Islam sebagai studi ekstra kurikuler di sekolahsekolah gubernemer (pemerintah).

Setelah Indonesia merdeka pemikiran K.H Ahmad Dahlan tentang konsep kurikulum pendidikan Islam tersebut sebagian diadopsi dalam pendidikan Nasional. Pada masa orde lama, pemerintah tetap mempertahankan pendidikan ala Belanda. Sekolah Pemerintah tidak mengajarkan pendidikan agama sebagai pelajaran wajib. Pendidikan agama merupakan studi pilihan yang dapat diberikan sesuai persetujuan orang tua. Lembaga pendidikan Islam tetap tidak mengajarkan sains modern, perubahan signifikan terjadi pada orde baru.

Berangkat dari pengalaman politik dan visi pembangunan bangsa, pemerintah orde baru membuat kebijakan yang sangat penting. Pendidikan agama merupakan studi wajib di semua jenjang dan jenis pendidikan. Siswa di sekolah umum wajib mengikuti pelajran agama sesuai dengan keyakinannya. Selain itu, pemerintah juga mulai mengembangkan sistem pendidikan madrasah yang di dalamnya diajarkan studi agama dan sains. Sejak diberlakukannya Surat Keputusan tiga Menteri, Komposisi studi sains (pelajaran non agama) justru lebih banyak di bandingkan dengan studi agama (Karel A. Steenbrink, 1986: 3).

Secara sosiologis, kebijakan pendidikan pemerintah Orde Baru memiliki pengaruh positif dalam masyarkat Islam. Konfergensi sosial, politik dan keagamaan yang memulai teramati pada awal 1990-an, sebagiannya disebebkan oleh faktor pendidikan (Kuntowijoyo, 1997). Sekat-sekat sosial antara priyayi, santri, abangan memudar karena putra putri keluarga santri, priyayi dan abangan belajar dibangku pendidikan yang sama, belajar dari guru yang sama dan referensi pembelajran yang relatif 
sama.

Bagi Muhammadiyah, realitas sosial tersebut memiliki dua sisi yang berbeda. Disatu sisi, cita-cita ideal manusia dan masyarakat yang dicitacitakan Muhammadiyah mulai tercapai. Benih-benih yang disemaikan Muhammadiyah tumbuh dan berkembang dalam kehidupan bangsa. Pada sisi lainnya, "penyeragaman" pendidikan era Orde Baru berakibat pada hilangnya ciri khusus atau identitas pendidikan Muhammadiyah. Apa yang membedakan sekolah atau madrasah Muhammadiyah dengan yang lainnya? Jawaban yang seringkali dikemukakan adalah di Muhammadiyah terdapat studi Al-Islam dan Kemuhammadiyahan. Karena itulah secara implisit kedua mata pelajaran tersebut dinamankan muatan atau kulikurum "ciri khusus" yang membedakan pendidikan Muhammadiyah dengan yang lainnya.

Berdasarkan paparan yang dikemukakan di atas, temuan penelitian tentang konsep kurikulum pendidikan Islam menurut K.H. Ahmad Dahlan, yaitu integralistik antara muatan kurikulum umum dan muatan kurikulum agama, yang dapat dirinci sebagai berikut:

(1) Al-Qur'an

(2) Hadits,

(3) Akhlaq (budi pekerti), dan

(4) Ilmu-ilmu Sosial

Jika dikaitkan dengan apa yang direkomendasikan oleh Syed Ali Ashraf tentang kurikulum pendidikan Islam, maka dapat dilihat sebagaimana pada tabel berikut ini:

Tabel

Kurikulum Pendidikan Islam

\begin{tabular}{|l|l|}
\hline $\begin{array}{l}\text { Kurikulum Pendidikan Islam } \\
\text { Menurut K.H. Ahmad Dahlan }\end{array}$ & \multicolumn{1}{|c|}{$\begin{array}{c}\text { Kurikulum Pendidikan Islam Menurut } \\
\text { Syed Ali Ashraf }\end{array}$} \\
\hline Al-Qur'an & $\begin{array}{l}\text { AL-Qur'an } \\
\text { yang meliputi: } \\
\text { 1. Membaca (Qira'ah), menghafal } \\
\text { (hifz), dan interpretasi (tafsir) }\end{array}$ \\
& $\begin{array}{l}\text { 2. Sirah Nabi Muhammad SAW, para } \\
\text { sahabat nabi, dan umat Islam periode } \\
\text { awal }\end{array}$ \\
& $\begin{array}{l}\text { 3. Tauhid } \\
\text { 4shul Fiqh dan Fiqh }\end{array}$ \\
& Bahasa Arab Al-Qur'an (Fonologi, \\
& sintaksis, dan semantik) \\
\hline Hadits & Sunnah \\
\hline Akhlaq (budi pekerti) & Pengetahuan Acquiered-Muktasabat (ilmu- \\
\hline Ilmu-ilmu Sosial & ilmu hasil pencarian dan pemikiran \\
& manusia), seperti: \\
\hline
\end{tabular}

104 Dhian Wahana Putra: Konsep Pendidikan Islam Dalam Perspektif K.H. Ahmad Dahlan, Hal 99-107 


\begin{tabular}{|c|c|}
\hline & $\begin{array}{l}\text { 1. Imaginatif-Seni: Seni Islam dan } \\
\text { Arsitektur, bahasa dan sastra } \\
\text { 2. Ilmu-ilmu intelektual: studi sosial } \\
\text { (teoretik), filsafat, pendidikan, } \\
\text { ekonomi, ilmu-ilmu politik, sejarah, } \\
\text { peradaban Islam, geografi, sosiologi, } \\
\text { ilmu bahasa, psikologi, dan } \\
\text { Antropologi. } \\
\text { 3. Ilmu-ilmu pengetahuan Alam } \\
\text { (teoretik): Filsafat Ilmu, matematik, } \\
\text { statistik, fisika, ilmu kimia dan lain- } \\
\text { lain } \\
\text { 4. Ilmu-ilmu terapan: Rekayasa dan } \\
\text { Teknologi, kedokteran, pertanian dan } \\
\text { kehutanan } \\
\text { 5. Praktek: Perdagangan, Ilmu-ilmu } \\
\text { administrasi, Ilmu-ilmu } \\
\text { perpustakaan, Ilmu-ilmu Rumah } \\
\text { Tangga, dan Ilmu-ilmu Komunikasi. } \\
\text { Materi tambahan: Filsafat Islam, } \\
\text { Perbandingan Agama, dan } \\
\text { Kebudayaan Islam }\end{array}$ \\
\hline
\end{tabular}

Metode Pendidikan Islam menurut KH. Agama Islam.

\section{Ahmad Dahlan}

Dalam mengajarkan pengetahuan Agama Islam secara umum maupun membaca Al-Qur'an, K.H. Ahmad Dahlan menerapkan metode pengajaran yang disesuaikan dengan kemampuan siswa sehingga mampu menarik perhatian para siswa untuk menekuninya. Tentu saja sebagian siswa merasa bahwa waktu pelajaran agama Islam pada hari Sabtu sore itu belum cukup sehingga banyak siswa, termasuk siswa yang tidak beragama Islampun datang ke rumah K.H. Ahmad Dahlan di kauman pada hari Ahad untuk bertanya maupun melakukan diskusi lebih lanjut tentang berbagai persoalan yang berhubungan dengan
Begitu pula dalam hal dakwah K.H. Ahmad Dahlan selalu menjelaskan dengan metode yang mudah dipahami oleh jama'ahnya. Sebagaimana saat ia memberi pengajian subuh dimasjid, dengan berulang-ulang ia mengupas surat AlMa'un saja. Dimintanya perhatian para hadirin bagaimana melaksanakan ayatayat itu. Meski semua telah hafal, namun belum tentu mengamalkannya. Demikianlah, metode pengajaran yang dilakukan Ahmad Dahlan, tidak hanya menekankan pemahaman secara teoritis namun juga sangat memperhatikan pada hal-hal yang bersifat praktis. Demikian ini dimaksudkan agar materi yang diajarkan dalam mengajar dan berdakwah tidak hanya sekadar dipahami, tapi juga dihayati 
dan dipraktekkan dalam kehidupan seharihari.

Gambaran jelas dari deskrpsi tersebut dapat disimpulkan bahwa metode pendidikan Islam menurut K.H. Ahmad Dahlan, sebagai berikut:

(1) Menyesuaikan dengan kemampuan siswa sehingga mampu menarik perhatian para siswa untuk menekuninya,

(2) Menggunakan metode hiwar/ pengulangan,

(3) Keseimbangan dan proporsionalitas antara teori dan praksis.

\section{KESIMPULAN}

1. Tujuan pendidikan menurut K.H. Ahmad Dahhlan dapat diambil kesimpulan sebagai berikut (1) Pendidikan islam hendaknya diarahkan pada usaha membentuk manusia muslim yang berbudi pekerti luhur, alim dalam agama, luas pandangan dan paham masalah ilmu keduniaan, serta bersedia berjuang untuk kemajuan masyarakatnya, (2) Tujuan pendidikan yang sempurna adalah melahirkan individu yang utuh menguasai ilmu agama dan ilmu umum, material dan spritual serta dunia dan akhirat, (3) Mempertajam daya intelektualitas dan memperkokoh spiritualitas.

2. Konsep Kurikulum Pendidikan Islam menurut K.H. Ahmad Dahlan, yaitu integralistik antara muatan kurikulum umum dan muatan kurikulum agama, yang dapat dirinci sebagai berikut:

(1) Al-Qur'an

(2) Hadits,

(3) Akhlaq (budi pekerti), dan
(4) Ilmu-ilmu Sosial

3. Metode pendidikan Islam menurut K.H. Ahmad Dahlan, sebagai berikut: Menyesuaikan dengan kemampuan siswa sehingga mampu menarik perhatian para siswa untuk menekuninya, Menggunakan metode hiwar/ pengulangan, Keseimbangan dan proporsionalitas antara teori dan praksis.

\section{DAFTAR PUSTAKA}

Al-Attas, Naquib, (1979). Aims and Onjectives of Islamic Education, King Abdul Aziz University. Jeddah.

Al-Abrasyi, Muhammad Athiyah. (1975). At-Tarbiyah Al-Islamiyah wa Falasifatuha. Kairo : Isa al-Bab al Halabi.

(1970). Dasar-dasar Pokok Pendidikan Islam. Jakarta : Bulan Bintang.

Ali Ashraf, Syed. (1989). Horison Baru Pendidikan Islam. Jakarta : Pustaka Firdaus.

Ali, Syed dan Husein, Syed Sajjad, (1986). Krisis Pendidikan Islam. Bandung : Risalah.

An-Nahlawi, Abd Rahman. (1992). Prinsip-prinsip Pendidikan Islam, Bandung : Diponegoro.

Ar-Rasyidin dkk,. (2005). Filsafat Pendidikan Islam. Jakarta : PT. Ciputat Pers.

Arikunto, Suharsimi, (2002). Prosedur Penelitian Suatu Pendekatan Praktek. Jakarta : PT. Rineka Cipta.

Azwar, Syaifudin, (2004). Metode Penelitian. Yogyakarta : Pustaka Pelajar. 
Fahmi, Asma Hasan, (1979). Sejarah dan Filsafat Pendidikan Islam. Jakarta : Bulan Bintang.

Hamid, Shalahuddin. (2003). Seratus Tokoh Islam Yang Paling Berpengaruh Di Indonesia, Jakarta : PT. Inti Media Cipta Nusantara.

Khozin. (2005). Menggugat Pendidikan Muhammadiyah. Malang : UMM Pers.

(2006). Jejak-Jejak Pendidikan Islam di Indonesia. Malang : UMM Pers.

Mujib, Abdul dkk. (2006). Ilmu Pendidikan Islam. Jakarta : Kencana.

Mu'ti, Abdul. (2012). Muhammadiyah untuk Kemanusiaan dan Peradaban Sang Surya Tiada Henti Menyinari Negeri. Surabaya : Hikmah Press.

Nata, Abuddin. (2001). Sejarah Pertumbuhan dan Perkembangan Lembaga-Lembaga Pendidikan Islam di Indonesia. Jakarta : Grasindo.

(2005). Tokoh-Tokoh Pembaruan Pendidikan Islam Indonesia, Jakarta : PT. Raja Grafindo.

Nasir, Ridwan. (2005). Mencari Tipologi Format Pendidikan Ideal. Yogyakarta : Pustaka Pelajar.

Nizar, Samsul. (2002). Filsafat Pendidikan Islam. Jakarta : Ciputat Pers.

Salam, Junus. (2009). K.H. Ahmad Dahlan Amal dan Perjuangannya, Tangerang : Al-Wasat Publishing House.

Saleh Abdullah, Abd Rahman. (1989). Educational Theory a Qur'anic Out Look. Makkah Al-Mukarromah : Ummu Al Qura University.
Shihab, Alwi. (2016). Membendung Arus Respon Gerakan Muhammadiyah Terhadap Penetrasi Misi Kristen di Indonesia. Yogyakarta : Suara Muhammadiyah,

Steenbrink, A. Karel. (1986). Pesantren, Madrasah, Sekolah. Jakarta : LP3ES.

Sucipto, Hery. (2010). K.H. Ahmad Dahlan Sang Pencerah, Pendidik dan Pendiri Muhammadiyah. Jakarta : Best Media Utama.

Subana dan Sudrajad. (2001). DasarDasar Penelitian Ilmiah. Bandung : Pustaka Setia.

Sugiyono. (2012). Metode Penelitian Kuantitatif Kualtitatif dan $R \& D$. Bandung : Alfabeta.

Syafii Maarif, Ahmad. (1985). Islam dan Masalah Kenegaraan. Jakarta : LP3ES.

Yunus, Mahmud. (1982). Sejarah Pendidikan Islam di Indonesia. Jakarta : Hidakarya Agung.

Zuhairini. (2004). Sejarah Pendidikan Islam. Jakarta : Bumi Aksara. 
